\title{
SCHEDULED CASTE STUDENTS IN THE CONTEXT TO HIGHER EDUCATION IN JAMMU AND KASHMIR
}

\author{
Mr. Bushan Kumar
}

\begin{abstract}
Ever since Indian higher education system treats education as a public good inevitably then it belongs to social sector. For years together it has been trying its level best to uplift the weaker section of our Indian society. This paper explore the barrier and enabler, identifies and analyses the social, personal, economic and educational problems Of the Scheduled Castes students (SCs) with reference to those who are pursuing and who did not pursue the higher education in their social contexts. The paper will focus on the higher education and Scheduled Caste in Indian and Jammu and Kashmir context and the role of Dr.B.R. Ambedkar in affirmative action in India. The rationale behind this paper is to analyze the barriers faced by SC students for not pursuing higher education, and to analyze the enablers which enable them to pursue higher education successfully. Paper will also highlight how some of the scheduled castes students successfully overcome to these issues and others failed in doing so. The data was collected through interview and analyze.
\end{abstract}

Key words: Barriers, Doda, Enabler, higher education and Scheduled caste.

\section{INTRODUCTION}

In the Indian Hindu society having the various castes, the scheduled caste is the one caste among them, generally the scheduled caste that caste that is belonging the lower status in the Indian context. The scheduled caste is generally social, cultural, educational, economic and politically backward class in the society, the scheduled caste is the legal and constitutional name given to the tradition known as "untouchable" class. The upper class was exploited the scheduled caste because their status was low, for this purpose the Government taken the initiative and formulate the schemes and reservation policy for the improvement and development of the scheduled caste. The scheduled caste students faced barrier and across it to go for pursuing the higher education, although education has proved to be the best means for their development, it has not reached the majority of the SCs both structurally and functionally. The students whose intended the higher 
Towards Excellence: An Indexed, Refereed \& Peer Reviewed Journal of Higher Education / Mr. Bushan Kumar/ Page 41-52

education they across the various barrier such as social, cultural, economic, personal and educational and engage the himself or herself for pursuing the higher education and the majority of the students not reach the higher education they dropout the after completion their secondary education the various factor responsible such as social, cultural, economic, personal and educational. The main causes for did not intend to go for higher education is illiteracy, poverty, unawareness, and guidance.

This study finds and analyzes the social, economic, personal and educational problem of scheduled caste students generally intended to go for higher education, drop out after completing secondary education and dropout at higher education level. The primary focuses of this study are:

- To analyze the barriers faced by SC students for not pursuing higher education.

- To analyze the enablers which enable the scheduled castes students to successfully go for higher education.

- To analyze why some of the scheduled castes students successfully go and others failed to go for higher education

\section{BACKGROUND OF CASTE AND CLASS IN INDIAN CONTEXT}

The four primary castes are Brahmin, (priests); Kshatriya, (warriors); Vaisya, (traders); and Shudra, (servants). Some people were born outside of (and below) the caste system. The scheduled caste is on the legal and constitution legend, the history of scheduled caste background government of India traced Act 1935, before that the Sis generally depressed class in the social context. In the society, there are some specific rule and regulation regarding the social, religious and educational life. The scheduled caste was not allowed to follow the rule and regulation because they belonging the lower caste and have lower status in the society; even they have no right to education religious like as upper caste. After the constitution enforced the scheduled caste was made under the chairmanship of Dr. B.R Ambedkar. At present the scheduled caste students having the special provision in Jammu and Kashmir as compare to the other state Inter-district recruitment passing of amended inter-district recruitment bill the J\&K Civil Services Decentralization and Recruitment Bill, 2009.

Ram Nath Kovind, who has been, was a lawyer who practiced in the Delhi High Court and the Supreme Court for 16 years. The Dalit leader first stepped into politics in 1994 when he was elected as a Rajya Sabha member from Uttar Pradesh. He served for two consecutive terms 
Towards Excellence: An Indexed, Refereed \& Peer Reviewed Journal of Higher Education / Mr. Bushan Kumar/ Page 41-52

for 12 years till March 2006. He represented India in the United Nations in New York and addressed United Nations General Assembly in October 2002 (Ram, 2017).

\section{Role of Dr B.R. Ambedkar in Affirmative Action}

"Reservation", also sometimes denoted as "affirmative action" or "positive discrimination", it refers to a policy or program, or giving certain preferences to certain groups (usually underrepresented groups) over the others (Sastra, 2016).

The Dr. B.R Ambedkar plays an important role to remove the social inequality in the Indian context; he is not only the political but also the social arrival of Gandhi. Among developing Countries, India has had perhaps the longest history of affirmative action to counter caste and ethnic discrimination (Revankar 1971). The first and foremost change and development of the scheduled caste students Ambedkar recommended was education. He aware of it and its importance and effect because having the experienced himself, the important aims of his movement to remove the caste system and untouchibility in the society. The political parties and government had taken notices of role Special provisions were made in the Constitution and development of SCs became a state responsibility. Untouchibility was declared abolished under Article17 of the Constitution. Article 46 provides that: 'The States shall promote with special Care the educational and economic interests of the weaker sections of the people and in particular of the Scheduled Castes and Scheduled Tribes and shall protect them from social injustice and all forms of exploitation.' Consequently, new avenues to enter into modern and secular sections of development have been opened to the SCs. Dr. B.R Ambedkar established the all India depressed classes' federation to support the advancement of the scheduled castes. He demanded reservations for the Scheduled castes in government services as well as other sectors(reservation policy india,2016).

Article 46 of the constitutions in 1950, the state shall per motes with special care the educational and economic interest of the weaker sections of the people, and in particular of the scheduled caste and the scheduled tribe shall protect them from social injustice and all forms of exploitation. Article 341 and 342 of the Constitution included a list of castes and tribes entitled to such provision, and the castes and the tribes included in these two lists were known as Scheduled Castes (SC) and Scheduled Tribes (ST) respectively. Also, the "special measures" could mean several measures other than reservation (Throat, 2007)

\section{Reservation for SC /ST and OBC}


Towards Excellence: An Indexed, Refereed \& Peer Reviewed Journal of Higher Education / Mr. Bushan Kumar/ Page 41-52

\begin{tabular}{|llll}
\hline SC & $15 \%$ & ST & $7.5 \%$ \\
\hline
\end{tabular}

\section{CLASS AND CASTE IN JAMMU AND KASHMIR}

Like as India in the Jammu and Kashmir state the Hindu society had been divided into the caste and sub-caste on the type of work and birth. The fourth caste, Sudhras is treated as the inferior class and afterward, they are called the "untouchable". The castes which were treated as untouchables in the State of Jammu and Kashmir included Megh, Doom, Chamar, Chura, Watal, Batwal, and Koli etc. The extent of this discriminatory attitude could be found in the educational institutions where a Rajput or Brahman boy objected to sitting beside a Chamar or Megh student.

Jammu And Kashmir State Maharaja Gulab Singh tried to improve the position of lower castes in the social context after Ranbir Singh first attracted attention toward untouchibility class. Hari Singh proclaimed untouchibility to be an offense in 1940. As untouchibility was retarding the progress and welfare of the Harijan community, a regulation, called the Removal of Untouchibility of Harijan Act of 1940, was passed by the State Government. conceded by the Pandits of Kashi at the instance of Maharaja Ranbir Singh that the outcasts and others similarly situated depressed classes should have chances of bettering their position and rising in the social scale.

\section{METHODOLOGY}

Semi-structured, in-depth interviews are utilized extensively as interviewing format possibly with an individual or sometimes even with a group. These types of interviews are conducted once only, with an individual, semi-structured interviews are based on semi-structured interview guide, which is a schematic presentation of questions or topics and needs to be explored by the interviewer. In order to have the interview data captured more effectively, recording of the interviews is considered an appropriate choice but sometimes a matter of controversy among the researcher and the respondent. Handwritten notes during the interview are relatively unreliable, and the researcher might miss some key points. the data collected through semi-structured interviews with scheduled caste students those who are intended to go for higher education and didn't intend to go for higher education in colleges and villages, the colleges include govt. degree college doda, degree college Thathri and degree college badhwarwa and villages include Moothi, Bhari, Roat, Mongata, Paki-hatti and khelani of district doda jammu and kashmir. 
Towards Excellence: An Indexed, Refereed \& Peer Reviewed Journal of Higher Education / Mr. Bushan Kumar/ Page 41-52

Purposive sampling was used to identify participants from each village of sampling strategy is commonly used in qualitative research to explicitly select participants whom will generate appropriate data, all interviews were conducted in doda the local language.

\section{FINDINGS}

The data show a wide range of barriers to prevent both boys and girls scheduled caste students those who intended to go for higher education and who didn't intend to go for higher education in district doda. almost all of the adolescent both boys and girls who dropped out of school or colleges more than one reason for dropping out, with not being interested in school or colleges and support from the family being prevalent. in contrast, a top-cited the reason in school. That emerged from the findings can be into macro-societal, educational, interpersonal, and individual factors. We developed a conceptual framework, based on the findings.

The qualitative analysis of the collected data from the scheduled caste students through the direct interview.

Diagram:

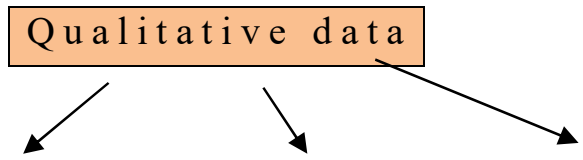

1: $\quad$ The scheduled caste students who are Drop out in $12^{\text {th }}$ clace
2: $\quad$ The scheduled caste students who are not pursuing the hicher education.
3: The scheduled caste students those who are nurcuino the hicher

Diagram: 5.1 showing the scheduled castes students face the barrier and drop out after the $12^{\text {th }}$ class.

1. Financial constraint

2. Lack of family support in terms of the financial, uniform, admission fee, transport fee, examination fee, room rents etc.

PERSONAL

1. Not interesting to pursuing the higher education in the higher institutions.

2. Due to the poor academic performance in the $12^{\text {th }}$ class standard.
1. Belief that there is no use of educating girls

2. Early marriage

3. Peer group influence

4. Illiteracy and unawareness
EDUCATIONA

L
1. Lack of positive attitude towards teacher

2. Lack of facilities for boys and girls

3. Lack of institutional facility

4. Access to government scheme 


\section{SOCIAL BARRIER}

\section{Belief that there is no use in educating girls}

The value a girl places on staying in school is strongly influenced by her community. Both in school and out of school adolescent girls felt that their communities valued educating boys more than educating girls. Those students who are drop out the 12th class especially the girls' students, some of them are the similar points of view they said that;

"our family are not support us to go to school, because they think that there is no value in educating girls because even if a girls were educated, there would no livelihood opportunities for her other than framing and manual lab our, especially girls from SCs castes. Our parents/guardian engaged us to do the domestic works and also help the mother in domestic

$$
\text { works". }
$$

\section{Early marriage}

The early marriage is another constraint among the scheduled caste in pursuing the education, Some of the scheduled caste students are unable to complete his/her school age after the second stage because their parents think about their marriage in these conditions the some of the viewpoints are as under;

Meetu Devi said that "when I am in the $11^{\text {th }}$ class the parents were thinking about my marriage because the environment of the community has influenced my parents and my parents also influenced me as well as my study."

Rakesh Kumar said that, "due o the poor academic achievement when I am disqualified in the $12^{\text {th }}$ class, my father told me you are unable to qualify the $10+2$ exam and why you are waste your time\& money. it is better I will do your marriage."

\section{Peer group influence}

Peer group influenced also responsible for the dropout among the scheduled caste both boys and girls at school levels, Some of them are the similar point of view: They said that: we are the ten members of the group, some of them they are interested to go to school daily some of them 
said that no need to go to school daily let we enjoy the full of day outside the school the other hand the female students had influenced the peer group some of the students are the similar points I am Reeta (R) stayed in the village the school distance is ten kilometres and I am single person no other friend are pursuing the regular education, my parents are not allow me alone to go to school and still I appear the 12th class exam unfortunately I am unsuccessful and stop the education in this stage. The scheduled caste students who belonging the rural and far flange area in district doda, especially students belonging the tehsil, Marmat villages are as Moothi, hambal, Bari, Roat, mongata, khelani and behouta.

\section{ECONOMIC BARRIER}

\section{Lack of support from family}

In some cases, the both boys and girls were interested in studying but there was a lack of support from family members to continue education. Lack of support was sometimes related to the fear of engaging in the some social activities. However, there were also two cases of physical abuse from the girl's father, which prevented one from attending school and created pressures to drop out of school for another. The some of them are some similar point regarding the lack of family supports in terms of financial conditions;

Suresh Kumar :( S) We are the six member of the family father is illiterate he is totally depend on the agriculture and hardly done the labours work there is no any resource of income. My parents are not able to pay the admission fee, tuitions fee, rent of room the senior secondary school is away from residence not only this but also purchasing the books, uniforms and day to day needs my school age. I am the one uniforms more than one years, this was the reason behind the drop out my school study.

Kamaljeet (K) My position among the third, I have two elder sisters who were totally illiterate and my father and mother also illiterate, I am suffering to seeking the help in my study.

\section{PERSONAL BARRIER}

\section{Lack of self interest}

Some of the scheduled caste students who are not pursuing the school education in $12^{\text {th }}$ class because they are not interested to pursuing higher education especially female students their parents engage them to domestic works, the some of them said that: 
Towards Excellence: An Indexed, Refereed \& Peer Reviewed Journal of Higher Education / Mr. Bushan Kumar/ Page 41-52

Rekha said that, "I am not interested to go to school because I think that there is the lot of girls students qualified in $12^{\text {th }}$ class and they are still unemployed, there are no use to go school daily and invest the money, time in school now I am helping the mother do the domestic works in day to day activities."

Kuldeep Kumar said that, "I am the eldest member among brother and sister of my family myself having the full of responsibility on my shoulder the first time I am appearing the $12^{\text {th }}$ class exam and I were failed, and think that this is the better to give the chance my sibling because in my home there is nobody who had helped me in my study."

\section{EDUCATIONAL BARRIER}

\section{Lack of facilities for boys and girls}

Another issue that arose during field visits was the lack of facilities for male and females students' especially female students at colleges. There is no hostel, facilities transport, separate classroom in these cases the various female students are not planning to pursue the higher education when I asked the female students some of them are similar points of view and the some of them are different views:

Rajni (R) I am not think or planned to pursue the higher because there is no separate class room the college is away from approximately $30 / 40$ kilometre.

\section{Lack of institution facilities}

The lack of educational institution facilities in term of colleges, in the district doda there are three colleges represent one main district Doda, second tehsil badhwarwa and third thathari, the tehsil gandho, molahir, khelani, goha, bahala those pupils(students) who belonging these thesils they are unable to pursuing the higher education. The availability of colleges are not the facilities available for boys and girls in the term of hostel, transport and separate class room especially for girls students the parents think that our girls students not a safe these type of circumstances in the field of education especially for pursuing higher education similar points regarding the lack of institution facilities:

Pawan Kumar (P) said that $\mathrm{i}$ have no another issue like academic performance, financial condition and the other social environment but institution is away from home. My parents not allow me to go away from home for pursuing the higher education. 
Diagram:5.2 Showing the Scheduled Castes Students who are pursuing the higher education and

\section{Across the barrier.}

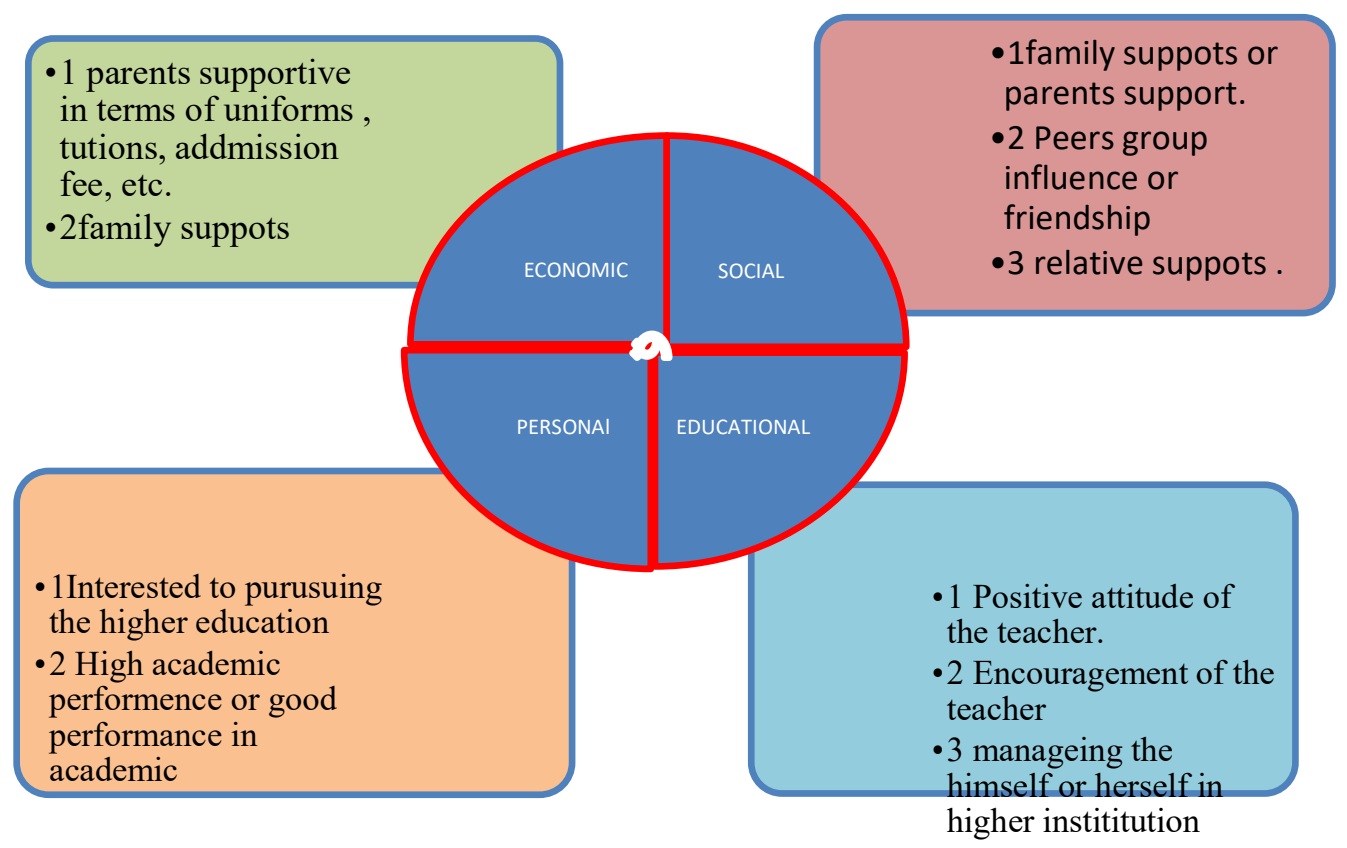

\section{Crossing the social barrier}

Some of the scheduled caste students across the social barrier and pursuing the higher education in the different colleges in the district Doda. As the investigator myself visits in the field asking about the problem those he/she faced at the time of getting the admission in the higher education the some of them are the similar points of view such as Davivder, shavani, parshotam; Parshotam; said that "I am in the M.A 4th semester when I seek the admission in B.A in the govt degree college doda the environment of the society is very bad as per my points of view because the society member said my father you think about the marriage of son, when the parents told me I rejected the view of my parents and reply him I want to continuous my study in this myself across the social barrier in the society." shavani; my parents not allow me for pursuing the higher education in the higher intuitions, when I completed the 12th the some environment of the community also influenced my parents and that situation my brother also helped me for pursuing the higher education not only this situation he is also helping me in my study he believe that the education of the girls should be equally as boys and think that the girls should be able to stand on their own two feet."

\section{Economic constraint}


The most of the scheduled caste students in the higher education they are faced the financial problem and across and managing. But they are managing the themselves in that circumstance, when I visit in the field for the purpose of data collection and interact with them through the interview. The some of them are the similar statement are as under : Manjet; : My father is poor we are the six member of the family he is doing the labour work but they are arranged money for my study. Sunil : I am also face the problem to pursuing the higher education but my family support me for pursuing the higher education still I am managing the govt provided the scholarship scheme and I am utilize the money in my favour.

\section{Educational problem}

The most of the scheduled caste students in higher education they across the educational problem through the tuition, seeking the help of the other. Among the scheduled caste students especially the females students ." Sunjata: My parents want my study in women colleges but unfortunately there are no women colleges available in the district Doda and my father to some extent agree to allow me for pursuing the higher education in colleges. Komal: said by "worth" I'm referring to not only the cost but also the debt. Some families can afford to write a check to cover the entire expense of today's college costs, but the overwhelming majority of families cannot do so. The quality of a college good for every student those who are pursuing the higher education in the higher institution.

\section{DISCUSSION}

This study has found a wide range among the scheduled caste students those who are intended to go for higher education and didn't intend to go for higher education in District Doda. At the macro-societal level, there was a belief that they will with their in-laws. The fear of her suspicions or actual "with the fellow macro-societal barrier. There were also barriers to, including poor quality, abusive teachers, teasing by boys, a lack of facilities for accessing government schemes. The main interpersonal factors which influenced her education included a lack of support, direct and indirect costs to, child marriage and the influence of peers. Finally, included girl's not valuing education, which in turn, influenced by the other barriers. In contrast, the key enablers stay in school, supportive teachers, peers in school, education herself.

\section{CONCLUSION}

This study has found numerous barriers and a few enablers to staying in the higher institutions of scheduled caste adolescent students both boys and girls in District Doda in Jammu and Kashmir. 
Some of these resonate with existing literature on the scheduled caste boys and girls to intended to going for higher education and didn't intended to going for higher education.. Education has numerous benefits for the scheduled caste students boys and girl. However, there are several challenges to staying in colleges for a scheduled caste adolescent student both boys 'and girls in the District Doda, which need to be addressed. Focusing on scheduled caste adolescent students, especially in rural District Doda, where they face a wide variety of issues is crucial to allowing them to reach their full potential.

The study highlights the importance of involving multiple stakeholders to overcome the barriers to education for low caste students, and of working to change beliefs and expectations around gender norms as well as improving scheduled caste students ' experiences of education in this setting. Ultimately, successful interventions will need to address changing gender norms and relationships at the macro-societal and family level as well as improve the quality and value of education. 
Towards Excellence: An Indexed, Refereed \& Peer Reviewed Journal of Higher Education / Mr. Bushan Kumar/ Page 41-52

\section{References}

1. Kashmir life (2018) Untouchibility Reforms in J\&K of International Journal of Novel Research in Humanity and Social Sciences Volume 2, Issue 4, this copy was excerpted from July - August 2015.

2. Bhaskar, A. (2017), The Law is clear: Reserved Category Candidates Are Entitled to General Seats on the Basis of Merit, Volume-4, Issue-6

3. Behera, S. (2015) .A status report of scheduled castes in higher education, International Journal in Management and Social Science. Vol.03 Issue-06.

4. Bhagavatheeswaran, L. et al. (2015) the barriers and enablers to education among scheduled caste and scheduled tribe adolescent girls in northern Karnataka, South India: A qualitative study. International Journal of Educational Development. Volume 49, No. 262

5. Kumar, R. (2015), "A study of impact of social environment on attitude of highly educated scheduled caste families towards social change", Journal of International Academic Research \& Management Communication. Volume 5, Issue4.

6. Kumar R. (2015) "A study of impact of higher education on attitude of scheduled caste families towards social change. International Research Journal of Human Resources and Social Sciences Volume-2, Issue-5

7. Tilak G. (2015) How Inclusive Is Higher Education in India? Social Change Sage Publications 45(2) 185-223.

8. Kumar, V. (2014), Inequality in India. Caste and Hindu Social Order, Transience , Vol. 5, Issue 1 ISSN 2191-1150

9. Abdul, A. (2011) Education for the economically and Socially Disadvantaged Groups in India: An Assessment Economic Affairs. Vol. 56 No. 2 June 2011 (Page 233-242).

10. Thorat, S. (2007), Reservation in employment, education and legislature -status emerging issues, working paper series volume 11

11. Zwart, F. (2000), the logic of affirmative action: Caste and class and quotas in India. actasocilogica, Volume -43.

12. Kirpal, V. (1985) Scheduled Caste and Tribe Students in Higher Education, A Study of an IIT

13. Chauhan, B, (1975) "Scheduled Caste and Education", Anu Publication, Delhi.

\section{Bushan Kumar Research Scholar \\ Central University of Kashmir Ganderbal Jammu and Kashmir, India}

